\title{
Differential interspecific incompatibility among Populus hybrids in sections Aigeiros Duby and Tacamahaca Spach
}

\author{
by A. Assibi Mahama1,2, Richard B. Hall ${ }^{1}$ and Ronald S. Zalesny Jr. ${ }^{3}$
}

\begin{abstract}
In our previous Populus breeding, compatible crosses between P. maximowiczii A. Henry and P. deltoides Bartr. ex Marsh corroborated the potential of interspecific hybrids, despite low seed set. Our current objective was to test the range of incompatibility among intraspecific and interspecific crosses using parental germplasm from the sections Aigeiros Duby (P. deltoides and $P$. nigra L.) and Tacamahaca Spach (P. maximowiczii). We determined the success rate of crosses, along with seed production and seedling viability. The success of crosses ranged from complete incompatibility to complete compatibility, with $29 \%$ to $85 \%$ of the transplanted germinants developing into healthy seedlings.
\end{abstract}

Key words: forest genetics, tree improvement, hybridization, hybrid poplar, Populus deltoides, P. nigra, P. maximowiczii

\section{RÉSUMÉ}

Au cours de nos précédents travaux d’amélioration génétique du Populus, des croisements compatibles entre P. maximowiczii A. Henry et $P$. deltoides Bartr. ex Marsh ont corroboré le potentiel des hybrides interspécifiques, malgré la faible quantité de semences. Notre objectif actuel était dévaluer le niveau d'incompatibilité parmi les croisements intraspécifiques et interspécifiques au moyen du plasma germinatif parental tiré de sections d'Aigeiros Duby (P. deltoides and P. nigra L.) et Tacamahaca Spach (P. maximowiczii). Nous avons déterminé le niveau de succès des croisements, ainsi que la production de semences et la viabilité des semis. Le niveau de succès des croisements va de l'incompatibilité totale à la compatibilité complète et entre $29 \%$ à $85 \%$ des embryons transplantées sont devenues des semis vigoureux.

Mots clés : génétique forestière, amélioration génétique, hybridation, peuplier hybride, Populus deltoides, P. nigra, P. maximowiczii

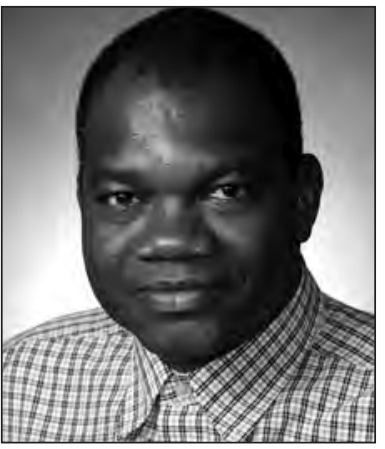

A. Assibi Mahama

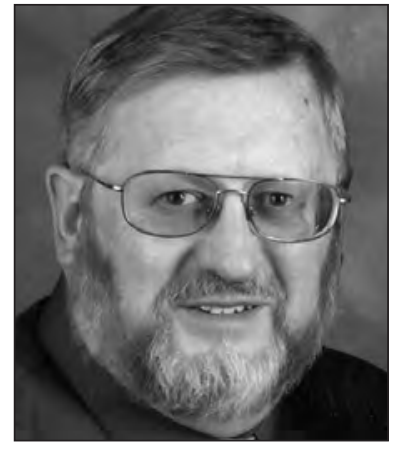

Richard B. Hall

\section{Introduction}

Interspecific hybrids within the genus Populus have resulted from both natural hybridization and planned breeding efforts (Willing and Pryor 1976, Ronald 1982, Eckenwalder 1984). Heterosis (i.e., hybrid vigour) of interspecific hybrids, along with traits such as disease/pest resistance and elevated rooting ability, have supported their use in a variety of applications (Riemenschneider et al. 2001, Zalesny et al. 2007, 2009). Nevertheless, difficulties in producing such hybrids have resulted

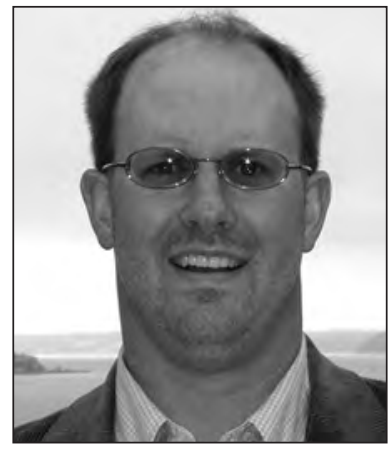

Ronald S. Zalesny Jr. from prefertilization and postzygotic barriers, along with hybrid inviability (Melchior and Seitz 1968, Guries and Stettler 1976, Stettler and Guries 1976, Stettler et al. 1996).

Overall, the broad variation in the success of hybridization has ranged from complete incompatibility to complete compatibility (Stettler et al. 1996). Typically, intersectional crosses between species belonging to the sections Aigeiros Duby, Tacamahaca Spach, and Populus (formerly Leuce) Duby have exhibited directional incongruity (Hogenboom 1973). Success in crossing Aigeiros and Tacamahaca species was observed to be dependent upon the direction in which the cross was made (Zsuffa 1975, Guries and Stettler 1976, Gaget et al. 1984, Villar et al. 1987). For example, although successful crosses between $P$. deltoides Bartr. ex Marsh (eastern cottonwood) ' $\mathrm{D}$ ' and $P$. maximowiczii A. Henry (Japanese poplar) ' $\mathrm{M}$ ' $(\mathrm{D} \times \mathrm{M})$ have led to significant levels of breeding and deployment (Ecken-

\footnotetext{
${ }_{1}^{1}$ Iowa State University, Department of Natural Resource Ecology and Management, 339 Science II, Ames, IA 50011, USA.

${ }^{2}$ Current address: Pioneer Hi-Bred International, Inc., 7200 NW 62nd Avenue, P.O. Box 184, Johnston, IA 50131, USA.

${ }^{3}$ U.S. Forest Service, Northern Research Station, Institute for Applied Ecosystem Studies, 5985 Highway K, Rhinelander, WI 54501, USA. Corresponding author. E-mail: rzalesny@fs.fed.us
} 
walder 2001), the reciprocal cross $(M \times D)$ has been less successful and seldom reported. The intrasectional cross between $P$. deltoides and $P$. nigra L. (European black poplar) 'N' $(\mathrm{D} \times \mathrm{N}$, successful) and its reciprocal $(\mathrm{N} \times \mathrm{D}$, failure $)$ have exhibited similar results (Melchior and Seitz 1968, Castiglione et al. 1993, Dickmann 2001). Zsuffa et al. (1999) described one-way barriers between Aigeiros and Tacamahaca species, along with an embryo rescue technique used to offset the impacts of these barriers. Although embryo rescue and ovary/ovule culture are alternative modes of increasing the success of certain crosses (Kouider et al. 1984, Savka et al. 1987, Raquin et al. 1993, Mofidabadi et al. 1998), normal seedling production is possible for some combinations without such methods, including crosses involving the section Populus (Ronald 1982).

Although the range in successful hybridization exists, reports about complete compatibility/incompatibility dominate the published literature. There is scarce information about partial interspecific incompatibility, especially where few but viable seeds were produced and the need for embryo rescue was eliminated. Our previous breeding experience revealed compatible $\mathrm{M} \times \mathrm{D}$ crosses using a specific $P$. maximowiczii clone (904-2) as the female parent with multiple $P$. deltoides males. The crosses exhibited low seed set, but viable seedlings were produced. Therefore, our objective of the current study was to test the range of incompatibility among intraspecific and interspecific crosses using parental germplasm from the sections Aigeiros $(P$. deltoides and $P$. nigra) and Tacamahaca (P. maximowiczii). We compared the success rate of crosses, along with seed production and seedling viability.

The ideal experiment would have been to make crosses and reciprocals for comparison. However, reciprocal crosses are not possible because the genus Populus is dioecious. Using siblings would be the closest method to making reciprocal crosses. Unfortunately, given lack of material availability, we had only one sibling pair each for $P$. deltoides and $P$. maximowiczii crosses to use in our experiment. Most of the crosses were done with unrelated parents of each species. Nevertheless, building on the pioneering work of Dr. Ernst Schreiner, Dr. Louis Zsuffa and other poplar breeders, we believe these data are meaningful for those attempting crosses with similar parental material. Our information is especially important given that there are very few recently published reports on North American Populus breeding.

\section{Materials and Methods}

\section{Parent material and population formation}

The origins of and variation within different Populus species have been described in detail (Heilman and Stettler 1985, Rajora and Zsuffa 1990, Eckenwalder 1996). In this paper we use the Populus section names as specified by Eckenwalder (1996), but we have retained the species nomenclature for $P$. maximowiczii that has been previously used in the breeding literature. Populus maximowiczii is currently classified as a subspecies of P. suaveolens Fischer (Eckenwalder 1996, Dickmann 2001).

During the 2000, 2001, and 2002 breeding seasons, male and female flowering branch materials were collected in January and/or February and used immediately or stored at $4^{\circ} \mathrm{C}$ until being used within one to two weeks of collection. Pollen of some clones from other breeding programs also was acquired during these seasons. Parent trees of $P$. deltoides were located at the Iowa State University breeding orchard $5 \mathrm{~km}$ north of Ames, Iowa, USA, and in wild stands in the Midwestern United States. Some breeding materials of P. maximowiczii were from parent trees located at the Maple Arboretum near Toronto, Ontario, which represented old clonal selections from Japan. Additional P. maximowiczii breeding materials came from Québec provincial breeding orchards near Sainte-Foy, Québec. The P. nigra pollen was supplied by the National Institute for Agricultural Research (INRA) at Orléans, France via Boise Cascade, and from P. nigra var. Italica in Grand Rapids, Michigan, USA collected by Pat McGovern. Parental clones with unique traits or that were used in crosses producing novel progeny are listed in Table 1 . Information on other parents is available upon request.

Two-way crosses were made in 2000, 2001, and 2002 using $P$. deltoides, $P$. maximowiczii, and $P$. nigra parents in the following combinations (the female parent is listed first for all cross designations): $\mathrm{D} \times \mathrm{D}, \mathrm{D} \times \mathrm{M}, \mathrm{D} \times \mathrm{N}, \mathrm{M} \times \mathrm{D}$, and $\mathrm{M} \times$ $\mathrm{N}$ (Table 2). Overall, 271 crosses were attempted using 29 unique female parents (22 P. deltoides, 7 P. maximowiczii) and 38 unique male parents ( 30 P. deltoides, 5 P. maximowiczii, 3 $P$. nigra) (Table 2$)$. Known compatible crosses $(\mathrm{D} \times \mathrm{D}, \mathrm{D} \times \mathrm{M}$, and $\mathrm{D} \times \mathrm{N}$ ) were included as controls.

\section{Pollen forcing and collecting}

Male scions were handled following the general procedures used in other Populus programs (Stanton and Villar 1996), with the following specifics. The base of each male floral branch was cut under water and placed in reservoirs of $2 \%$ Floralife solution (Floralife, Inc., Burr Ridge, Illinois, USA) at room temperature. The reservoirs were isolated in individual pollen forcing chambers in separate greenhouse rooms. Floralife solution was added to each reservoir to maintain the hydration level of the floral branches until pollen extraction was completed. Working with one clone at a time in order to avoid contamination, pollen was collected, sieved to clean it of debris and dried in small vials over Drierite (W.A. Hammond Drierite Company Ltd., Xenia, Ohio, USA) in capped jars in a refrigerator. Pollen was used immediately or stored at $4^{\circ} \mathrm{C}$ until needed. Pollen was tested for viability before use according to a modified 2,3,5-triphenyl tetrazolium chloride (TTC) method of Rajora and Zsuffa (1986) (A. A. Mahama, unpublished data). Pollen for one day's breeding activity was rehydrated for two to three hours before use by dispensing the pollen into a $50 \times 15 \mathrm{~mm}$ Pyrex petri dish and placing it inside a $90 \times 50 \mathrm{~mm}$ petri dish, adding approximately $1 \mathrm{ml}$ of water to the larger dish, and covering the dish to slowly raise the internal relative humidity and allow the pollen to gradually rehydrate (Worsley 1959).

\section{Pollination and seedling production}

Female catkin development through to mature seed in $P$. deltoides and Tacamahaca species requires at least six weeks, well beyond what can be adequately supported by unrooted cuttings (Stanton and Villar 1996). Either rooting or grafting of dormant female scions is the standard practice in these taxa. In our work, female floral branches were removed from cold storage at $4^{\circ} \mathrm{C}$ and grafted onto the rootstock of 'Siouxland' $(\mathrm{D} \times \mathrm{N}$ genotype) in the greenhouse. High humidity was 
Table 1. Parental clones with unique traits or that were used in crosses producing novel progeny in a breeding study testing the range of incompatibility within the genus Populus. Information on other parents is available upon request.

\begin{tabular}{|c|c|c|c|c|}
\hline Species $^{\mathbf{a}}$ & Clone & $\begin{array}{l}\text { Geographic origin } \\
\text { (organization) }\end{array}$ & Latitude, Longitude & Significant characteristic(s) \\
\hline \multicolumn{5}{|l|}{ Female parents } \\
\hline \multirow[t]{3}{*}{ P. deltoides } & $80 x 01038$ & $\begin{array}{l}\text { Rockwood, IL, USA } \times \\
\text { St. Jacob, IL, USA }\end{array}$ & $\begin{array}{l}37.8^{\circ} \mathrm{N}, 89.4^{\circ} \mathrm{W} \times \\
38.7^{\circ} \mathrm{N}, 89.8^{\circ} \mathrm{W}\end{array}$ & $\begin{array}{l}\text { In } 2 / 5 \mathrm{D} \times \mathrm{M} \text { crosses, some dwarf } \\
\text { seedlings were produced, } 1 \text { cross failed, } \\
1 \text { cross produced only a few seeds. }\end{array}$ \\
\hline & 119.16 & $\begin{array}{l}111-3 \times 282-14 \\
\text { (Univ. of Minnesota) }\end{array}$ & $n a^{b}$ & $\begin{array}{l}\text { In } 2 / 4 \mathrm{D} \times \mathrm{M} \text { crosses, some dwarf } \\
\text { seedlings were produced. }\end{array}$ \\
\hline & 7300501 & Grand Chain, IL, USA & $37.3^{\circ} \mathrm{N}, 89.0^{\circ} \mathrm{W}$ & $\begin{array}{l}\text { Best parent in } \mathrm{D} \times \mathrm{D} \text { crosses, but in } 3 / 4 \text { of } \\
\mathrm{D} \times \mathrm{M} \text { crosses, some dwarf seedlings were } \\
\text { produced. }\end{array}$ \\
\hline \multirow[t]{7}{*}{ P. maximowiczii } & $897-1$ & Japan (Univ. of Toronto) & $44.9^{\circ} \mathrm{N}, 143.5^{\circ} \mathrm{W}$ & $\begin{array}{l}\text { In } 1 / 12 \mathrm{M} \times \mathrm{D} \text { crosses, a few viable seedlings } \\
\text { were produced, rest failed. }\end{array}$ \\
\hline & $898-1$ & Japan (Univ. of Toronto) & $43.9^{\circ} \mathrm{N}, 143.3^{\circ} \mathrm{W}$ & $\begin{array}{l}\text { In } 3 / 3 \mathrm{M} \times \mathrm{D} \text { crosses, only non-viable seeds } \\
\text { were produced. }\end{array}$ \\
\hline & $904-2$ & Japan (Univ. of Toronto) & $43.7^{\circ} \mathrm{N}, 143.4^{\circ} \mathrm{W}$ & $\begin{array}{l}\text { In } 8 / 8 \mathrm{M} \times \mathrm{D} \text { crosses, all gave reliable seed } \\
\text { and seedling production. }\end{array}$ \\
\hline & $1050-10$ & Japan (Univ. of Toronto) & na & $\begin{array}{l}\text { In } 5 / 6 \mathrm{M} \times \mathrm{D} \text { crosses, a limited number of } \\
\text { viable seeds were produced, } 1 \text { cross failed. }\end{array}$ \\
\hline & $1051-10$ & Japan (Univ. of Toronto) & na & $\begin{array}{l}\text { In } 3 / 9 \mathrm{M} \times \mathrm{D} \text { crosses, a limited number of } \\
\text { viable seeds were produced, } 1 \text { of these } \\
\text { families included some vine-like plants, } \\
6 / 9 \text { crosses failed. }\end{array}$ \\
\hline & 77341 & $\begin{array}{l}\text { Japan (Québec Ministry } \\
\text { of Forestry) }\end{array}$ & na & $\begin{array}{l}\text { In } 5 / 5 \mathrm{M} \times \mathrm{D} \text { crosses, no seeds were } \\
\text { produced. }\end{array}$ \\
\hline & 77441 & $\begin{array}{l}\text { Japan (Québec Ministry } \\
\text { of Forestry) }\end{array}$ & na & $\begin{array}{l}\text { In } 10 / 10 \mathrm{M} \times \mathrm{D} \text { crosses, either no or } \\
\text { non-viable seeds were produced. }\end{array}$ \\
\hline \multicolumn{5}{|l|}{ Male parents } \\
\hline P. deltoides & $7302801^{\mathrm{c}}$ & McClure, IL, USA & $37.3^{\circ} \mathrm{N}, 89.3^{\circ} \mathrm{W}$ & $\begin{array}{l}\text { In } 1 / 7 \mathrm{M} \times \mathrm{D} \text { crosses, some vine-like plants } \\
\text { were produced, } 4 / 7 \text { produced no seed. }\end{array}$ \\
\hline \multirow[t]{3}{*}{ P. maximowiczii } & $900-2$ & Japan (Univ. of Toronto) & $44.8^{\circ} \mathrm{N}, 143.2^{\circ} \mathrm{W}$ & $\begin{array}{l}\text { In } 3 / 6 \mathrm{D} \times \mathrm{M} \text { crosses, some dwarf seedlings } \\
\text { were produced. }\end{array}$ \\
\hline & $1051-4$ & Japan (Univ. of Toronto) & na & $\begin{array}{l}\text { In } 3 / 6 \mathrm{D} \times \mathrm{M} \text { crosses, some dwarf seedlings } \\
\text { were produced. }\end{array}$ \\
\hline & 77331 & $\begin{array}{l}\text { Japan (Québec Ministry } \\
\text { of Forestry) }\end{array}$ & na & $\begin{array}{l}\text { In } 1 / 6 \mathrm{D} \times \mathrm{M} \text { crosses, some dwarf seedlings } \\
\text { were produced. }\end{array}$ \\
\hline
\end{tabular}

${ }^{a}$ Authorities for the species are: P. deltoides Bartr. ex Marsh; P. maximowiczii A. Henry (now considered a subspecies of $P$. suaveolens Fischer).

bNot available.

'This male parent was previously shown to be heterozygous for a Melampsora leaf rust resistance allele (Tabor et al. 2000).

maintained for these grafted units (i.e., Siouxland rootstock plus grafted female floral branch) by placing them in polyethylene enclosures prior to floral expansion. Early in the breeding season, the floral buds would stay dormant for up to three weeks; the breeding season had to be terminated when floral expansion began to happen within a few days of grafting when there was insufficient movement of water across the graft union to maintain catkin development. As the flower buds expanded, but before stigmas were exposed, units were isolated individually in N-Sulate fabric (DeWitt Company, Sikeston, Missouri, USA) supported by tomato cages, and checked regularly for flower development. At full flower expansion, while stigmas were exposed, pollen from desig- nated males was dusted on female flowers using camelhair brushes. Pollination was repeated once or twice at two-day intervals as needed to catch all stigmas in a receptive condition. We had previously found that two pollinations were sufficient to pollinate an entire catkin and ensure a good seed set when a cross was compatible. Pollinations were conducted from January through March each year. In general, three to 11 catkins were pollinated per cross. Units were checked regularly and isolation hoods removed when stigmas were no longer receptive (i.e., shrivelled and brown).

Records were kept of catkin and capsule development. At the onset of capsule dehiscence/seed-shed, cotton from individual crosses was checked for presence/absence of seeds. 
Table 2. Crossing year, cross type, number of female and male parents used, crosses attempted, and successful crosses based on the percent of germinants and seedlings recovered.

\begin{tabular}{|c|c|c|c|c|c|c|}
\hline Year & Cross $^{a}$ & Females & Males & $\begin{array}{l}\text { Crosses } \\
\text { attempted }\end{array}$ & Germinants ${ }^{b}$ & Seedlings ${ }^{c}$ \\
\hline \multirow[t]{3}{*}{2000} & $\mathrm{D} \times \mathrm{D}$ & 12 & 19 & 83 & $\begin{array}{c}93 \\
(77 / 83)\end{array}$ & $\begin{array}{c}29 \\
(8257 / 28120)\end{array}$ \\
\hline & $\mathrm{D} \times \mathrm{M}$ & 3 & 1 & 3 & $\begin{array}{c}100 \\
(3 / 3)\end{array}$ & $\begin{array}{c}49 \\
(514 / 1043)\end{array}$ \\
\hline & $\mathrm{D} \times \mathrm{N}$ & 9 & 3 & 13 & $\begin{array}{c}92 \\
(12 / 13)\end{array}$ & $\begin{array}{c}36 \\
(1331 / 3725)\end{array}$ \\
\hline \multirow[t]{4}{*}{2001} & $\mathrm{D} \times \mathrm{D}$ & 12 & 20 & 53 & $\begin{array}{c}89 \\
(47 / 53)\end{array}$ & $\begin{array}{c}75 \\
(4648 / 6206)\end{array}$ \\
\hline & $\mathrm{D} \times \mathrm{M}$ & 5 & 3 & 12 & $\begin{array}{c}100 \\
(12 / 12)\end{array}$ & $\begin{array}{c}77 \\
(745 / 963)\end{array}$ \\
\hline & $\mathrm{M} \times \mathrm{D}$ & 7 & 12 & 54 & $\begin{array}{c}31 \\
(17 / 54)\end{array}$ & $\begin{array}{c}59 \\
(680 / 1145)\end{array}$ \\
\hline & $\mathrm{M} \times \mathrm{N}$ & 2 & 1 & 2 & $\begin{array}{c}50 \\
(1 / 2)\end{array}$ & $\begin{array}{c}50 \\
(6 / 12)\end{array}$ \\
\hline \multirow[t]{3}{*}{2002} & $\mathrm{D} \times \mathrm{D}$ & 7 & 8 & 31 & $\begin{array}{c}94 \\
(29 / 31)\end{array}$ & $\begin{array}{c}85 \\
\text { (2 206/2 597) }\end{array}$ \\
\hline & $\mathrm{D} \times \mathrm{M}$ & 4 & 5 & 18 & $\begin{array}{c}89 \\
(16 / 18)\end{array}$ & $\begin{array}{c}62 \\
(1747 / 2799)\end{array}$ \\
\hline & $\mathrm{D} \times \mathrm{N}$ & 2 & 1 & 2 & $\begin{array}{c}100 \\
(2 / 2)\end{array}$ & $\begin{array}{c}55 \\
(119 / 215)\end{array}$ \\
\hline
\end{tabular}

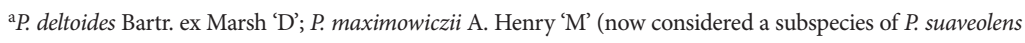
Fischer); P. nigra L. 'N'.

bercent of crosses producing germinants. The number of successful families out of the number of crosses attempted is listed in parentheses.

'Percent of initial germinants producing viable seedlings. The number of viable seedlings out of the number of initial transplants is listed in parentheses.

Table 3. Total number of crosses and capsules sampled across 2000, 2001, and 2002.

\begin{tabular}{ccc}
\hline Cross $^{\text {e }}$ & Crosses & Capsules \\
\hline $\mathrm{D} \times \mathrm{D}$ & 4 & 40 \\
$\mathrm{D} \times \mathrm{M}$ & 5 & 50 \\
$\mathrm{M} \times \mathrm{D}^{\mathrm{a}}$ & 4 & 40 \\
$\mathrm{M} \times \mathrm{D}^{\mathrm{b}}$ & 6 & 60 \\
$\mathrm{M} \times \mathrm{D}^{\mathrm{c}}$ & 8 & 80 \\
$\mathrm{M} \times \mathrm{D}^{\mathrm{d}}$ & 5 & 30 \\
$\mathrm{M} \times \mathrm{N}$ & 1 & 15 \\
\hline
\end{tabular}

${ }^{a}$ Female M (904-2) successfully used in previous breeding with D (impetus for current $\mathrm{M} \times \mathrm{D}$ crosses).

${ }^{b}$ New M females producing viable seeds (1050-10, 1051-10, 897-1).

${ }^{\mathrm{N} N e w} \mathrm{M}$ females producing nonviable seeds (77441, 898-1).

${ }^{\mathrm{d}}$ New $\mathrm{M}$ female producing no seeds (77341).

'P. deltoides Bartr. ex Marsh 'D'; P. maximowiczii A. Henry 'M' (now considered a subspecies of $P$. suaveolens Fischer); P. nigra L. 'N'.

The number of seeds per capsule for most crosses was sampled. Six to 15 capsules were sampled per cross (Table 3). The contents of the capsules from a single cross were spread on Peat-Lite (Conrad Fafard, Inc., Agawam, Massachusetts, USA) potting mix in trays and kept under mist. Trays were checked for germination and the production of germinants from three to 21 days after planting. Germinants beginning to produce true leaves were transplanted to flats with individual cells filled with the same potting mix, maintaining the identity of each seed lot.

\section{Data collection and analysis}

We determined the success rate of crosses (i.e., number of crosses successfully producing seeds and germinants), number of seeds per capsule (except the $\mathrm{D} \times \mathrm{N}$ crosses), and seedling viability (i.e., successful development of transplanted germinants into fieldplantable seedlings). Abnormal seedling traits (e.g., dwarf or vine-like seedlings) also were recorded (Table 1). The vine-like seedlings did not exhibit upright growth, but rather grew out horizontally like a ground-cover vine.

The success rate and seedling viability data were evaluated non-parametrically using a Chi-square $\left(\chi^{2}\right)$ test from frequency counts to analyze differences among $\mathrm{D} \times \mathrm{D}$, $\mathrm{D} \times \mathrm{M}, \mathrm{D} \times \mathrm{N}$, and $\mathrm{M} \times \mathrm{D}$ crosses (Table 2). The data from the $\mathrm{M} \times \mathrm{N}$ crosses were not statistically analyzed because of insufficient sample size. The mean number of seeds per capsule was proportional to the variance for each cross. Typically in such cases a square root transformation is conducted. However, instead of a square root transformation, the number of seeds data were subjected to analyses using PROC MIXED (SAS Institute, Inc. 2004), assuming a fixed main effect for cross. This analysis method was conducted because the homogeneity of error variances assumption was not met and using PROC MIXED supports calculation of appropriate standard errors for making mean comparisons under such conditions. There were similar variance structures between $\mathrm{D} \times \mathrm{D}$ and $\mathrm{D} \times \mathrm{M}$ crosses, and between $\mathrm{M} \times \mathrm{D}$ and $\mathrm{M} \times \mathrm{N}$ crosses. Thus, data for each pair of crosses were pooled and two variance subgroups were used in the analysis to increase the pooled degrees of freedom associated with crosses in the $F$ variance ratio, along with degrees of freedom for the estimation of least-squares means. The Satterthwaite approximation was used to estimate degrees of freedom. A Tukey-Kramer adjustment at $\alpha=0.05$ was used to compare means among crosses.

\section{Results}

The success rate of crosses producing seeds and viable germinants ranged from $31 \%$ to $100 \%$, while the percent of initial germinants producing viable seedlings ranged from $29 \%$ to $85 \%$ (Table 2). The success rate, number of seeds per capsule, and seedling viability across the 2000, 2001, and 2002 breeding seasons differed among crosses $(P<0.0001$ for all traits). The $\mathrm{D} \times \mathrm{D}$ crosses were compatible with 153 successful families produced out of 167 crosses attempted (92\% success). Eighteen to 49 seeds per capsule were produced, with a mean of $30.5 \pm 1.1$ seeds (Fig. 1). The $\mathrm{D} \times \mathrm{D}$ seeds were viable, germinating under mist and producing germinants that, when transplanted, developed into healthy seedlings at a rate of $41 \%$ 


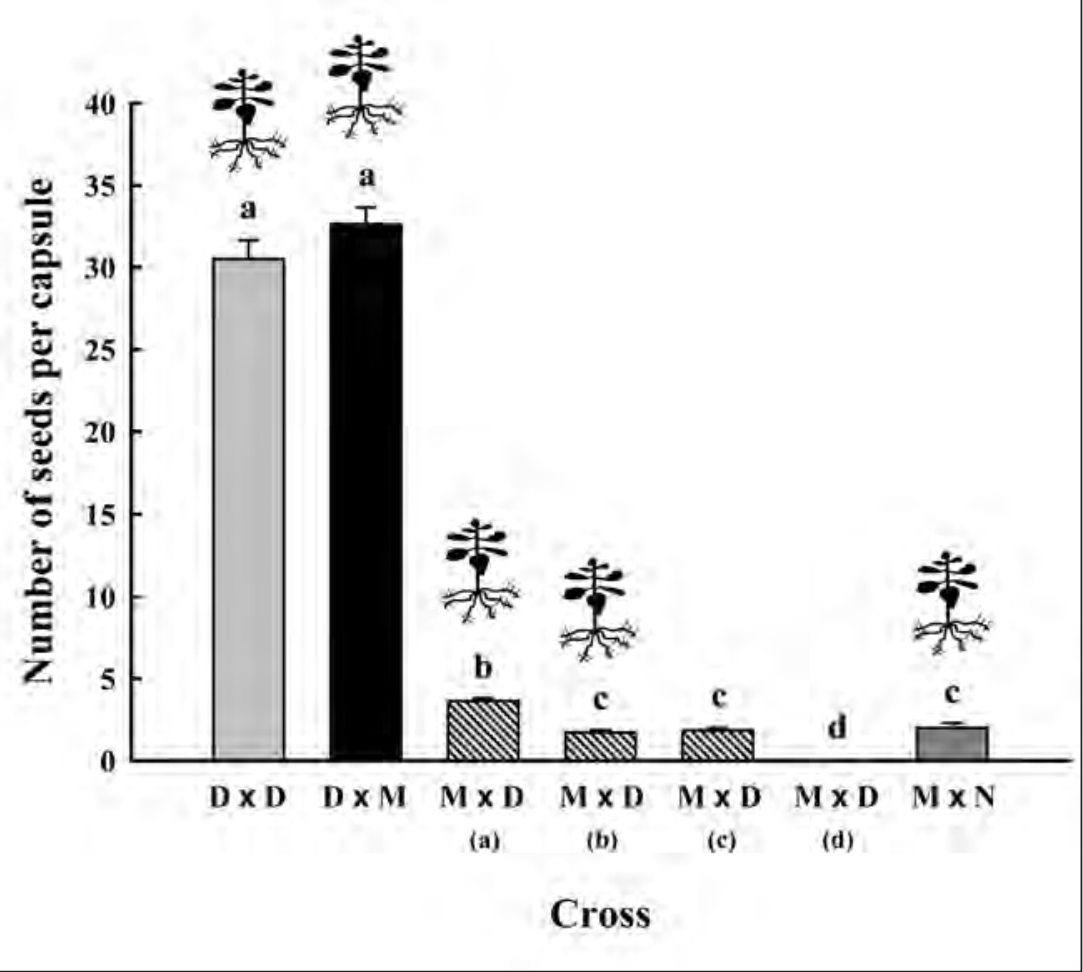

Fig. 1. Number of seeds per capsule for families developed in a Populus breeding study testing the range of incompatibility among crosses. Authorities for the species are: $P$. deltoides Bartr. ex Marsh 'D'; P. maximowiczii A. Henry 'M' (now considered a subspecies of $P$. suaveolens Fischer); $P$. nigra $\mathrm{L}$. 'N'. Different females were used for $\mathrm{M} \times \mathrm{D}$ crosses: (a) female $\mathrm{M}$ (clone 904-2) successfully used in previous breeding with $\mathrm{D}$ (impetus for current $M \times D$ crosses), (b) new $M$ females (clones 1050-10, 1051-10, 897-1) producing viable seeds, (c) new M females (clones 77441, 898-1) producing nonviable seeds, and (d) new $\mathrm{M}$ female (clone 77341) producing no seeds. Each bar represents the mean with one standard error. Bars with the same letter are not different $(\alpha=0.05)$. Trees above bars indicate that transplanted germinants developed into viable seedlings that were capable of being planted in the field.

(15 111 seedlings were viable out of 36923 initial germinants transplanted). The $\mathrm{D} \times \mathrm{M}$ crosses were compatible with 31 successful families out of 33 crosses attempted (94\% success). In addition, 22 to 48 seeds per capsule were produced, with a mean of $32.6 \pm 1.0$ seeds (Fig. 1 ). Most seeds produced germinants that developed into normal seedlings at a rate of $63 \%$ (3006 seedlings out of 4805 germinants). However, a substantial number of dwarf plants developed in the following $\mathrm{D} \times \mathrm{M}$ families: $7300501 \times 77331,7300501 \times 1051-4,7300501 \times 900$ $2,80 \times 01038 \times 1051-4,80 \times 01038 \times 900-2,119.16 \times 900-2$, and $119.6 \times 1051-4$ (Table 1$)$. Although the number of seeds per capsule was not sampled for the $\mathrm{D} \times \mathrm{N}$ crosses, 14 families were compatible out of 15 crosses attempted (93\% success), and $37 \%$ of the germinants developed into viable seedlings (1450 seedlings out of 3940 germinants). The $\mathrm{M} \times \mathrm{D}$ crosses exhibited a $31 \%$ success rate (17 families out of 54 crosses) and a broad range of compatibility, whereby $59 \%$ of the germinants developed into healthy seedlings (680 seedlings out of 1145 germinants). The successful female $P$. maximowiczii parent (clone 904-2) previously used in our breeding program produced one to 10 seeds per capsule, with a mean of $3.6 \pm 0.2$ seeds, which developed into viable seedlings (Fig. 1; [a]). We classified the other female $P$. maximowiczii parents used for the first time in the current study into three response groups, based on seed production and germinant viability (Fig. 1; [b], [c], [d]). Crosses of the first group (b) involving P. maximowiczii female clones 897-1, 1050-10, and 1051-10 (Table 1) produced one to three seeds per capsule, with a mean of $1.7 \pm 0.2$ seeds, which developed into viable seedlings. Some vine-like plants developed for the $\mathrm{M} \times$ D family 1051-10 × 7302801 (Table 1). Crosses of the second group (c) involving $P$. maximowiczii female clones 77441 and 898-1 (Table 1) produced one to four seeds per capsule, with a mean of $1.9 \pm 0.1$ seeds. However, seeds of group c were not viable, and, therefore, no seedlings were produced. Crosses of the third group (d) involved the $P$. maximowiczii female clone 77341 (Table 1), were incompatible, and failed to produce seed. Furthermore, one of the two $\mathrm{M} \times \mathrm{N}$ crosses was compatible (50\% success) and produced one to three seeds per capsule, with a mean of $2.0 \pm 0.3$ seeds (Fig. 1). Most of the $\mathrm{M} \times \mathrm{N}$ seeds were viable, germinating under mist and producing germinants that, when transplanted, developed into healthy seedlings at a rate of $50 \%$ (six seedlings out of 12 germinants).

\section{Discussion}

There was broad variation for incompatibility among the crosses in the current study, with the success of crosses ranging from $0 \%$ to $100 \%$, the number of seeds per capsule ranging from 0 to 49 , and the percent of transplanted germinants developing into field-plantable seedlings ranging from $0 \%$ to $76 \%$. The number of seeds per capsule was similar to that for crosses among species belonging to all Populus sections (Knox et al. 1972, Willing and Pryor 1976), along with individual species such as $P$. deltoides that has produced one to 60 seeds (Bessey 1904, Farmer and Nance 1968, Hardin 1984). The broad genotypic differences for seed production in the current study were similar to those previously reported (Stettler and Guries 1976, Stettler et al. 1980, Ronald 1982). However, seed production was consistent within any clone used as the female parent. That is, the crosses of any individual female either produced many seeds, few seeds, few non-viable seeds, or no seeds.

Most crosses produced germinants that developed into healthy seedlings that were ready for deployment in field plantings. Overall, our results corroborated those reported in the literature for compatibility of intraspecific $\mathrm{D} \times \mathrm{D}$ crosses and interspecific $\mathrm{D} \times \mathrm{M}$ and $\mathrm{D} \times \mathrm{N}$ crosses (Melchior and Seitz 1968, Zsuffa 1975, Stettler et al. 1996). Partial compatibility existed for the $\mathrm{M} \times \mathrm{D}$ crosses, with a range of no seeds to few viable seeds being produced. Whereas the intersec- 
tional cross $\mathrm{N} \times \mathrm{M}$ is compatible and has been exploited throughout North America and Europe (Dickmann 2001), reciprocal $\mathrm{M} \times \mathrm{N}$ crosses have exhibited variable success (Stout and Schreiner 1933). The $\mathrm{M} \times \mathrm{N}$ cross in the current study was partially compatible, agreeing with the results of Zsuffa et al. (1999). Given low seed set in partially compatible $\mathrm{M} \times \mathrm{D}$ and $\mathrm{M} \times \mathrm{N}$ crosses, doing more pollinations for each specific cross should enable production of enough progeny for genetic and breeding studies (Willing and Pryor 1976) or confirm the incompatibility of that specific cross.

We believe prefertilization and postzygotic crossing barriers, and perhaps, hybrid inviability, may have been underlying mechanisms leading to our results (Melchior and Seitz 1968, Guries and Stettler 1976, Stettler and Guries 1976, Stettler et al. 1996). Incompatibility among intersectional crosses can be the result of the lack of penetration of the pollen tube into the stigma (Guries and Stettler 1976). However, the crosses have been successful when using a mixture of viable incompatible pollen and inviable compatible pollen (i.e., mentor/recognition pollen) to overcome the crossing barriers (Stettler 1968, Knox et al. 1972, Stettler and Guries 1976, Willing and Pryor 1976, Stettler et al. 1980). In contrast, the use of such techniques was not needed for intersectional Populus $\times$ Aigeiros and Populus $\times$ Tacamahaca hybrids (Ronald 1982). Partial compatibility of our $\mathrm{M} \times \mathrm{D}$ and $\mathrm{M} \times \mathrm{N}$ crosses may have resulted from the successful penetration and fertilization by some pollen grain nuclei in generally incompatible crosses managing to develop tubes that penetrated and fertilized ovaries of the female (Knox et al. 1972, Stettler et al. 1980). For example, of seven $P$. maximowiczii clones used as females in our $\mathrm{M} \times \mathrm{D}$ crosses, only one clone (77441) mated with different males produced few seeds that did not germinate. Clone 77441 also produced a few non-viable seeds with $P$. nigra pollen (MI Lombardy). In contrast, the $P$. maximowiczii female clone 897-1 produced a successful $\mathrm{M} \times \mathrm{N}$ cross (897$1 \times$ MI Lombardy). In addition, clone 897-1 crossed with multiple $P$. deltoides males produced a range of success from no seed production to 16 germinants. Completely seedless capsules, irrespective of the male $P$. deltoides parent used, were observed from $\mathrm{M} \times \mathrm{D}$ crosses involving the $P$. maximowiczii clone 77341, while viable seedlings were produced when using the P. maximowiczii female clone 904-2 with four out of the five $P$. deltoides males crossed with 77341 .

Maternal genotypes within the same species have exhibited marked differences in flowering, capsule and catkin retention, and seed production, maturation and shedding (Stettler and Guries 1976, Stettler et al. 1980). Such variation can lead to false conclusions of lack of hybridization rather than poor or no germination of hybrid seeds present. For example, some of our $\mathrm{M} \times \mathrm{D}$ crosses produced seeds that did not germinate. However, the number of seeds was great enough that the lack of germinant production most likely was due to postzygotic barriers or hybrid inviability rather than prefertilization barriers (Zsuffa et al. 1999). For example, we observed split green capsules with seeds that did not produce germinants, despite having normal capsule walls that were retained throughout the breeding cycle.

\section{Conclusion}

This work demonstrates that enough seedlings can be produced without the use of embryo rescue from the right combinations of $P$. maximowiczii and $P$. deltoides or $P$. nigra males to create populations for field testing and selection. Because cytoplasmic inheritance is through the female parent (Smith and Sytsma 1990, Rajora et al. 1992), this offers the possibility of finding unique capabilities from crosses that have not been typically made because incompatibility was assumed to be a barrier. The results of this study also identify specific parents that could be used in basic research on incompatibility mechanisms, dwarfism, and vine-like growth in intersectional crosses of Populus species.

\section{Acknowledgements}

Ron Zalesny presented the results of this study at the 2007 Annual Meeting of the Poplar Council of Canada; September 16-21, 2007; Quebec City, Quebec. This research was funded by the U.S. Forest Service, Northern Research Station, subcontract 19XSZ269C with the Bioenergy Feedstock Development Program of the United States Department of Energy at the Oak Ridge National Laboratory; the Iowa Agriculture and Home Economics Experiment Station, Ames, Iowa, Project No. 3905, and supported by McIntire Stennis and State of Iowa funds. We thank Dr. Ken J. Moore (ISU Agronomy) for statistical advice. We are grateful to the following people for review of earlier versions of the manuscript: Edmund Bauer, Robert Bridges, David Coyle, Eric Gustafson, Bernie McMahon, Neil Nelson, Tom Schmidt, Adam Wiese, and Jill Zalesny.

\section{References}

Bessey, C.E. 1904. The number and weight of cottonwood seeds. Science 20: 118-119.

Castiglione, S., G. Wang, G. Damiani, C. Bandi, S. Bisoffi and F. Sala. 1993. RAPD fingerprints for identification and for taxonomic studies of elite poplar (Populus spp.) clones. Theoret. Appl. Genet. 87: 54-59.

Dickmann, D.I. 2001. An overview of the genus Populus. In D.I. Dickmann, J.G. Isebrands, J.E. Eckenwalder and J. Richardson (eds.). Poplar Culture in North America. Part A, Chapter 1. pp. 1-42. NRC Research Press, National Research Council of Canada, Ottawa.

Eckenwalder, J.E. 1984. Natural intersectional hybridization between North American species of Populus (Salicaceae) in sections Aigeiros and Tacamahaca. II. Taxonomy. Can. J. Bot. 62: 325-335.

Eckenwalder, J.E. 1996. Systematics and evolution of Populus. In R.F. Stettler, H.D. Bradshaw Jr., P.E. Heilman and T.M. Hinckley (eds.). Biology of Populus and Its Implications for Management and Conservation. Part I, Chapter 1. pp. 7-32. NRC Research Press, National Research Council of Canada, Ottawa.

Eckenwalder, J.E. 2001. Descriptions of clonal characteristics. In D.I. Dickmann, J.G. Isebrands, J.E. Eckenwalder and J. Richardson (eds.). Poplar Culture in North America. Part B, Chapter 13. pp. 331-382. NRC Research Press, National Research Council of Canada, Ottawa.

Farmer, R.E., Jr. and W.L. Nance. 1968. Crossing eastern cottonwood in the greenhouse. Proc. Intl. Plant Prop. Soc. 17: 333-338.

Gaget, M., C. Saïd, C. Dumas and R.B. Knox. 1984. Pollen-pistil interactions in interspecific crosses of Populus (sections Aigeiros and Leuce): pollen adhesion, hydration and callose responses. J. Cell Sci. 72: 173-184.

Guries, R.P. and R.F. Stettler. 1976. Pre-fertilization barriers to hybridization in the poplars. Silvae Genet. 25: 37-43.

Hardin, E.D. 1984. Variation in seed weight, number per capsule and germination in Populus deltoides Bartr. trees in southeastern Ohio. Amer. Mid. Nat. 112: 29-34.

Heilman, P.E. and R.F. Stettler. 1985. Genetic variation and productivity of Populus trichocarpa and its hybrids. II. Biomass production in a 4-year plantation. Can. J. For. Res. 15: 384-388. 
Hogenboom, N.G. 1973. A model for incongruity in intimate partner relationships. Euphytica 22: 219-233.

Knox, R.B., R.R. Willing and L.D. Pryor. 1972. Interspecific hybridization in poplars using recognition pollen. Silvae Genet. 21: 65-69.

Kouider, M., R.M. Skirvin, K.P. Saladin, J.O. Dawson and J.J. Jokela. 1984. A method to culture immature embryos of Populus deltoides in vitro. Can. J. For. Res. 14: 956-958.

Melchior, G.H. and F.W. Seitz. 1968. Interspezifische Kreuzungssterilität innerhalb der Pappelsektion Aigeiros. Silvae Genet. 17: 88-93.

Mofidabadi, A.J., A.R. Modir-Rahmati, and A. Tavesoli. 1998. Application of ovary and ovule culture in Populus alba L. $\times P$. euphratica Oliv. hybridization. Silvae Genet. 47: 332-334.

Rajora, O.M. and L. Zsuffa. 1986. Pollen viability of some Populus species as indicated by in vitro pollen germination and tetrazolium chloride staining. Can. J. Bot. 64: 1086-1088.

Rajora, O.M. and L. Zsuffa. 1990. Allozyme divergence and evolutionary relationships among Populus deltoides, P. nigra, and P. maximowiczii. Genome 33: 44-49.

Rajora, O.P., J.W. Barrett, B.P. Dancik and C. Strobeck. 1992. Maternal transmission of mitochondrial DNA in interspecific hybrids of Populus. Curr. Genet. 22: 141-145.

Raquin, C., L. Troussard and M. Villar. 1993. In-ovary embryo culture as a tool for poplar hybridization. Can. J. Bot. 71: 1271-1275.

Riemenschneider, D.E., W.E. Berguson, D.I. Dickmann, R.B. Hall, J.G. Isebrands, C.A. Mohn, G.R. Stanosz and G.A. Tuskan. 2001. Poplar breeding and testing strategies in the north-central U.S.: demonstration of potential yield and consideration of future research needs. For. Chron. 77: 245-253.

Ronald, W.G. 1982. Intersectional hybridization of Populus sections, Leuce-Aigeiros and Leuce-Tacamahaca. Silvae Genet. 31: 94-99.

SAS Institute, Inc. 2004. SAS/STAT 9.1 User's Guide. Cary, NC. Savka, M.A., J.O. Dawson, J.J. Jokela and R.M. Skirvin. 1987. A liquid culture method for rescuing immature embryos of eastern cottonwood. Plant Cell Tiss. Org. Cult. 10: 221-226.

Smith, R.L. and K.J. Sytsma. 1990. Evolution of Populus nigra (Sect. Aigeiros): Introgressive hybridization and the chloroplast contribution of Populus alba (Sect. Populus). Amer. J. Bot. 77: 1176-1187.

Stanton, B.J. and M. Villar. 1996. Controlled reproduction of Populus. In R.F. Stettler, H.D. Bradshaw Jr., P.E. Heilman and T.M. Hinckley (eds.). Biology of Populus and Its Implications for Management and Conservation. Part I, Chapter 1. pp. 113-138. NRC Research Press, National Research Council of Canada, Ottawa, ON.
Stettler, R.F. 1968. Irradiated mentor pollen: its use in remote hybridization of black cottonwood. Nature 219: 746-747.

Stettler, R.F. and R.P. Guries. 1976. The mentor pollen phenomenon in black cottonwood. Can. J. Bot. 54: 820-830.

Stettler, R.F., R. Koster and V. Steenackers. 1980. Interspecific crossability studies in poplars. Theoret. Appl. Genet. 58: 273-282.

Stettler, R.F., L. Zsuffa and R. Wu. 1996. The role of hybridization in the genetic manipulation of Populus. In R.F. Stettler, H.D. Bradshaw Jr., P.E. Heilman and T.M. Hinckley (eds.). Biology of Populus and Its Implications for Management and Conservation. Part I, Chapter 4. pp. 87-112. NRC Research Press, National Research Council of Canada, Ottawa, ON.

Stout, A.B. and E.J. Schreiner. 1933. Results of a project in hybridizing poplars. J. Hered. 24: 216-229.

Tabor, G.M., T.L. Kubisiak, N.B. Klopfenstein, R.B. Hall, and H.S. McNabb, Jr. 2000. Bulked segregant analysis identifies molecular markers linked to Melampsora medusae resistance in Populus deltoides. Phytopathol. 90: 1039-1042.

Villar, M., M. Gaget, C. Saïd, R.B. Knox and C. Dumas. 1987. Incompatibility in Populus: structural and cytochemical characteristics of the receptive stigmas of Populus alba and P. nigra. J. Cell Sci. 87: 483-490.

Willing, R.R. and L.D. Pryor. 1976. Interspecific hybridisation in poplar. Theoret. Appl. Genet. 47: 141-151.

Worsley, R.G.F. 1959. The processing of pollen. Silvae Genet. 8: 143-148.

Zalesny, R.S. Jr., R.B. Hall, J.A. Zalesny, B.G. McMahon, W.E. Berguson, and G.R. Stanosz. 2009. Biomass and genotype $\times$ environment interactions of Populus energy crops in the Midwestern United States. BioEnergy Res. 2: 106-122.

Zalesny, J.A., R.S. Zalesny, Jr., D.R. Coyle and R.B. Hall. 2007. Growth and biomass of Populus irrigated with landfill leachate. For. Ecol. Manage. 248: 143-152.

Zsuffa, L. 1975. A summary review of interspecific breeding in the genus Populus L. In D.P. Fowler and C.W. Yeatman (eds.). Proceedings of the $14^{\text {th }}$ Meeting of the Canadian Tree Improvement Association. Part 2, Symposium on Interspecific and Interprovenance Hybridization in Forest Trees. 28-30 August 1973. Fredericton, New Brunswick. pp. 107-123.

Zsuffa, L., D. Lin and P. Payne. 1999. One-way crossing barriers in some interspecific crosses of Aigeiros and Tacamahaca poplars. For. Chron. 75: 833-836. 